\title{
KOMUNIKASI DATA PADA SISTEM PELAPORAN KECELAKAAN PERAHU NELAYAN BERBASIS LORA
}

\author{
Fadli Padriyana $^{1}$, Firmansyah M.S.Nusuwars ${ }^{2}$, Nurul Hiron ${ }^{3}$ \\ Teknik Elektro, Fakultas Teknik, Universitas Siliwangi, Tasikmalaya, Indonesia ${ }^{1,3}$ \\ Informatika, Fakultas Teknik, Universitas Siliwangi, Tasikmalaya, Indonesia ${ }^{2}$ \\ Email : 167002046@student.ac.id ${ }^{1}$
}

\begin{abstract}
The job of being a fisherman is very risky, many factors that become the threat of work lurking a fisherman. Traditional fishermen are not facilitated with communication equipment that can support the safety of fishermen. So when something happens that can harm the fishermen, it cannot be handled immediately. In this research developed a wireless communication system based on LoRa to be able to monitor fishermen working at sea by online consisting of node devices attached to boats and gateways that function to forward data from the node device to the web server using the MQTT protocol, so that boat data can be monitored through the thingsboard dashboard. Data monitored include the location of fishing boats (longitude and latitude coordinates), the slope of the fishing boat (degree of roll and pitch) and also early warning. Testing the reliability of LoRa communication in marine communication scenarios is carried out by testing the distance of data transmission, data length and data delivery speed setting / air data rate with Line of Sight (LOS) condition at Sea directly. From the results of data transmission reliability testing using the communication module LoRa E32 915T20D is able to reach the furthest distance up to $2.4 \mathrm{Km}$ with the data send speed setting at $0.3 \mathrm{kbps}$ with an average delivery time delay /time on air that tends to increase with the increase in the length of data sent
\end{abstract}

Keywords : Air Data Rate, Line Of Sight, LoRa, Time On Air

\section{Abstrak}

Pekerjaan menjadi seorang nelayan sangat beresiko, banyak faktor yang menjadi ancaman kerja mengintai seorang nelayan. Nelayan tradisional tidak difasilitasi dengan peralatan komunikasi yang dapat menunjang keselamatan nelayan. Sehingga ketika terjadi sesuatu yang dapat membahayakan nelayan, tidak dapat dilakukan penanganan dengan segera. Dalam penelitian ini dikembangkan sistem komunikasi wireless berbasis LoRa untuk dapat memonitoring nelayan bekerja di laut secara online, yang terdiri dari node device yang terpasang pada perahu dan gateway yang berfungsi meneruskan data dari node device menuju web server menggunakan protokol MQTT, sehingga data perahu dapat dimonitoring melalui dasbor thingsboard. Data yang dimonitoring diantaranya lokasi perahu nelayan (koordinat longitude dan latitude), kemiringan perahu nelayan (derajat roll dan pitch) dan juga early warning. Pengujian keandalan komunikasi LoRa dalam skenario komunikasi laut dilakukan dengan mengujikan jarak pengiriman data, panjang data dan pengaturan kecepatan pengiriman data/ air data rate dengan kondisi Line of Sight (LOS) di Laut secara langsung. Dari hasil pengujian keandalan pengiriman data dengan menggunakan modul komunikasi LoRa E32 915T20D yaitu mampu menjangkau jarak terjauh hingga 2.4 Km dengan pengaturan kecepatan kirim data pada $0.3 \mathrm{kbps}$ dengan delay waktu pengiriman rata-rata/ time on air yang cenderung meningkat seiring pertambahan panjang data yang dikirim.

Kata kunci : Air Data Rate, Line Of Sight, LoRa, Time On Air

\section{PENDAHULUAN}

Menurut catatan Komite Nasional Kecelakaan Transportasi (KNKT), tren kecelakaan transportasi air terus meningkat dari tahun 2013 sebanyak 6 kecelakaan hingga tahun 2018 sebanyak 39 kecelakaan transportasi air terjadi. Penyebabnya beragam dari human error hingga faktor alam. Faktor alam menyumbang $38 \%$ penyebab kecelakaan transportasi air terjadi, diikuti oleh faktor human error $37 \%$, teknis $23 \%$ dan faktor lainnya 2\% [1]. Nelayan sehari-hari bekerja tentunya tidak terlepas dari alat transportasi air. Kapal nelayan tradisional tidak dirancang oleh arsitektur konstruksi kapal. Oleh karena itu tingkat stabilitas dan keamanan perahu nelayan tergolong rendah [2]. Nelayan tradisional juga tidak dibekali oleh peralatan komunikasi yang dapat menunjang keselamatan nelayan dalam bekerja.

Teknologi komunikasi dalam skenario maritim telah banyak diperbincangkan, banyak metode digunakan untuk memperoleh sistem yang lebih baik lagi [3]. LoRa adalah salah satu teknologi komunikasi nirkabel dengan jarak jangkauan yang cukup jauh dengan memanfaatkan teknik modulasi chirp spread spectrum sehingga teknik ini memiliki konsumsi daya yang rendah [4].

Berdasarkan uraian permasalahan tersebut, pada penelitian ini dirancang sebuah sistem komunikasi data berbasis LoRa wireless communication pada sistem pelaporan kecelakaan perahu nelayan. Sehingga posisi dan keadaan nelayan dapat termonitoring melalui web server Thingsboard.

\section{KAJIAN PUSTAKA}

A. $\quad \operatorname{LoRa}$

LoRa merupakan sebuah metode komunikasi nirkabel yang dapat menjangkau jarak komunikasi yang jauh namun dengan konsumsi energi dan ukuran data yang kecil [4]. LoRa bekerja pada frekuensi ISM (Industy, Scientific, Medical) band, yaitu di pita frekuensi 433, 868 dan 915 MHz.

Format packet data LoRa terdiri dari tiga komponen utama yaitu preamble, header (optional), dan payload. Terdapat dua jenis format packet data LoRa (Gbr. 1) yaitu 
Explicit header mode dan Implicit header mode. Pada jenis format explicit header mode terdapat header yang di dalamnya terdapat informasi payload length, coding rate. Dan CRC (Cyclic Redundancy Check) berfungsi untuk memeriksa error pada data digital. Sedangkan pada jenis implicit header mode, parameter payload length, coding rate, dan $\mathrm{CRC}$ tidak disertakan pada packet data, dan akan mengurangi time on air [5].

\begin{tabular}{|c|c|c|c|c|}
\hline & \multicolumn{2}{|c|}{ nHeader symbol } & \multicolumn{2}{|c|}{ Explicit Header Mode } \\
\hline Preamble & Header & CRC & Payload & $\begin{array}{c}\text { Payload } \\
\text { CRC }\end{array}$ \\
\hline nPreamble symbol & \multicolumn{3}{|c|}{ Implicit Header Mode } & \\
\hline Preamble & \multicolumn{2}{|c|}{ Payload } & $\begin{array}{c}\text { Payload } \\
\text { CRC }\end{array}$ & \\
\hline
\end{tabular}

\section{Gbr. 1 LoRa Format Packet Data}

Maka untuk mencari time on air (ToA) dapat dihitung menggunakan persamaan berikut:

$$
\text { ToA }=\text { Tpacket }=\text { Tpreamble }+ \text { Tpayload }
$$

\section{B. Chirp Spread Spectrum}

Pada dasarnya teknik modulasi ini memiliki kesamaan dengan narrowband perbedaannya teknik modulasi CSS memiliki power density yang rendah sehingga sinyal terlihat seperti noise, tidak akan dapat terbaca oleh perangkat narrowband dan hanya akan terbaca oleh perangkat dengan teknik modulasi dan memiliki pseudo noise yang sama [6]. Representasi sinyal CSS terhadap narrow band seperti terlihat pada Gbr. 2.

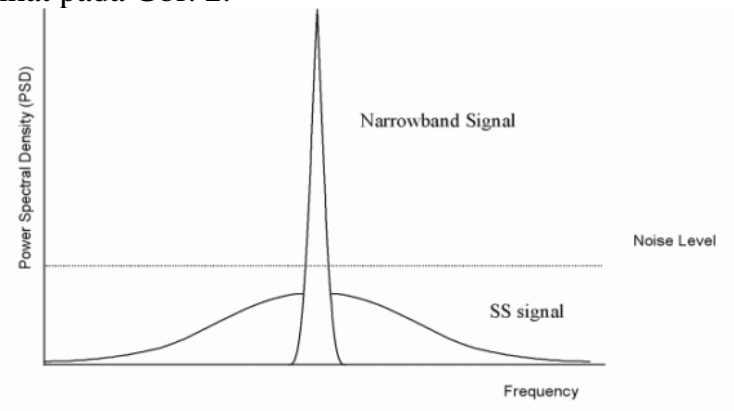

Gbr. 2 Perbandingan sinyal CSS dan Narrow band

CSS ini memiliki bentuk sinusoidal yang mengalami peningkatan frekuensi (up chirp) atau penurunan frekuensi (down chirp) terhadap waktu seperti pada Gbr. 3.

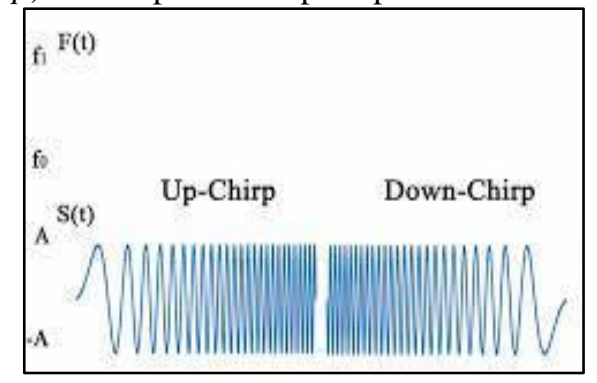

Gbr. 3 Bentuk sinyal CSS

\section{METODE}

A. Diagram Alur Penelitian
Pada Gbr. 4 merupakan diagram alur yang menjelaskan tahapan penelitian Komunikasi data pada sistem pelaporan kecelakaan perahu nelayan berbasis LoRa.

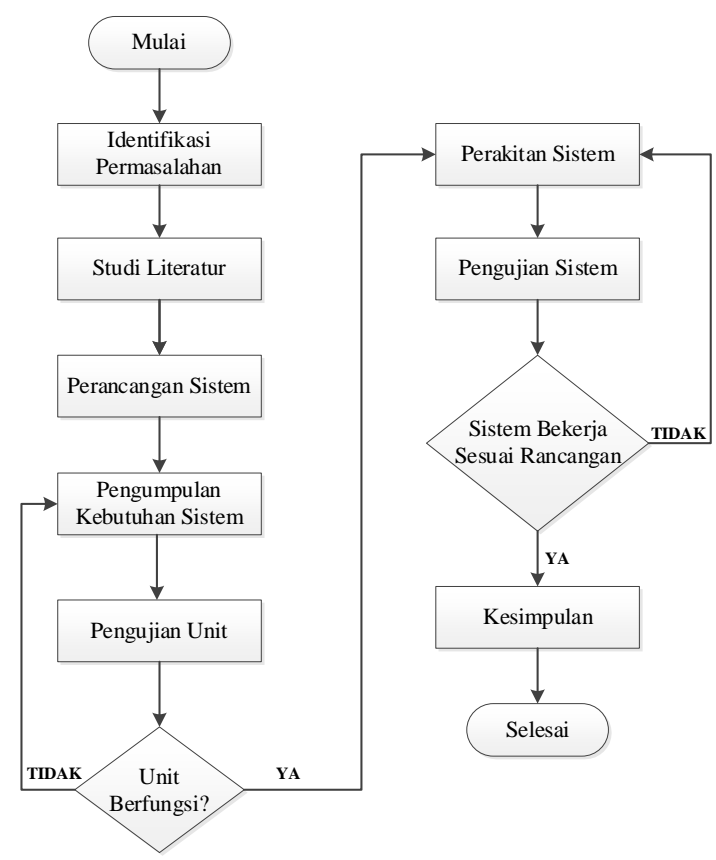

Gbr. 4 Diagram Alur Penelitian

\section{B. Perancangan Sistem}

Komponen yang digunakan pada penelitian ini yaitu Arduino Mega mini 2560, ESP32, LoRa E32 915T20D, LCD Touchscreen, Antenna Omni 915 MHz 5 dbi, GPS ublox M8, dan Sensor Accelerometer Gy-521. Arsitektur sistem terlihat pada Gbr. 5 .

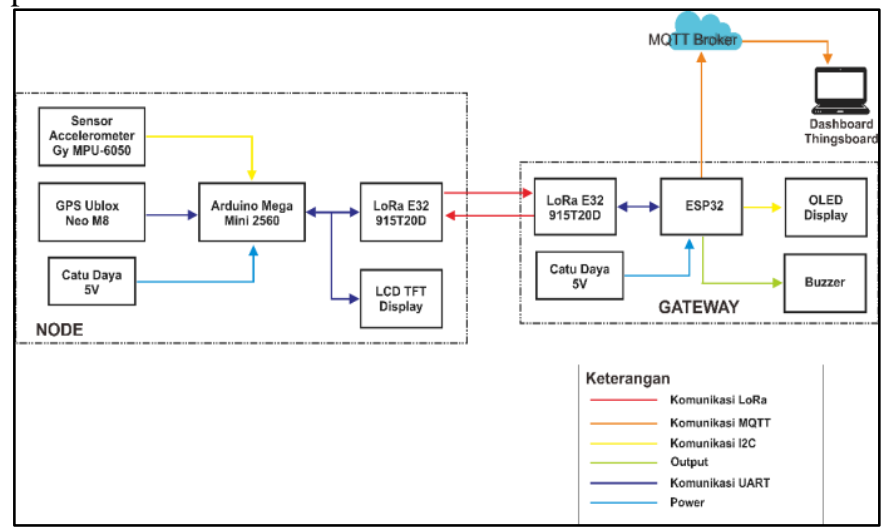

Gbr. 5 Arsitektur Sistem

\section{Perancangan Perangkat Keras}

Pada Sistem Komunikasi Data untuk sistem pelaporan kecelakaan perahu nelayan terdiri dari dua device yaitu node device dan gateway. Pada Gbr. 6 rancangan perangkat dari masing masing device.
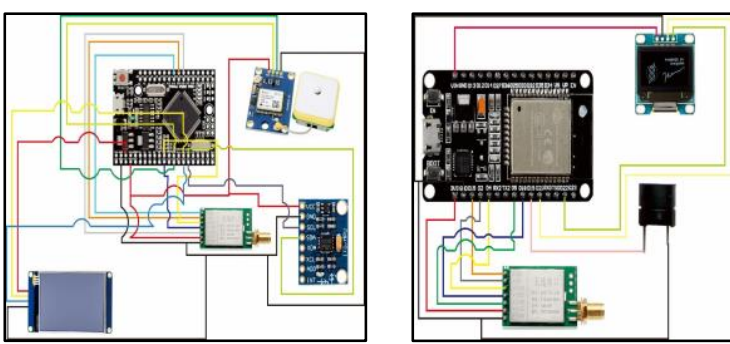
(a)

(b)

Gbr. 6 Perancangan Perangkat Keras (a) Node device (b)Gateway

Untuk konfigurasi pin tiap device dijelaskan pada Tbl. 1 dan Tbl. 2.

Tbl. 1 Konfigurasi pin Node Device

\begin{tabular}{cccc}
\hline No. & $\begin{array}{c}\text { Pin } \\
\text { MC }\end{array}$ & $\begin{array}{c}\text { Pin } \\
\text { Komponen }\end{array}$ & Nama Komponen \\
\hline 1 & $5 \mathrm{~V}$ & VCC & LCD Touchscreen \\
\hline 2 & $3.3 \mathrm{~V}$ & VCC & LoRa, GPS, Accelerometer \\
\hline 3 & GND & GND & Semua Komponen \\
\hline 4 & D32 & M0 & LoRa \\
\hline 5 & D34 & M1 & LoRa \\
\hline 6 & D10 & RX & LoRa \\
\hline 7 & D11 & TX & LoRa \\
\hline 8 & D36 & AUX & GPS \\
\hline 9 & D14 & RX & GPS \\
\hline 10 & D15 & TX & LCD Touchscreen \\
\hline 11 & D18 & RX & LCD Touchscreen \\
\hline 12 & D19 & TX & Accelerometer \\
\hline 13 & D20 & SDA & Accelerometer \\
\hline 14 & D21 & SCL &
\end{tabular}

Tbl. 2 Konfigurasi Pin Gateway

\begin{tabular}{cccc} 
No. & Pin MC & Pin Komponen & Nama Komponen \\
\hline 1 & Vin & VCC & Oled Display \\
\hline 2 & $3.3 \mathrm{v}$ & VCC & LoRa \\
\hline 3 & GND & GND & Semua Komponen \\
\hline 4 & D15 & M0 & LoRa \\
\hline 5 & D2 & M1 & LoRa \\
\hline 6 & D4 & RX & LoRa \\
\hline 7 & D18 & TX & LoRa \\
\hline 8 & D5 & AUX & LoRa \\
\hline
\end{tabular}

No. Pin MC Pin Komponen Nama Komponen

\begin{tabular}{cccc}
\hline 9 & D21 & SCL & Oled Display \\
\hline 10 & D22 & SDA & Oled Display \\
\hline 11 & D19 & Positive & Buzzer
\end{tabular}

\section{HASIL DAN PEMBAHASAN}

A. Implementasi

Pada Gbr. 7 dan Gbr. 8 merupakan implementasi rancang bangun alat.

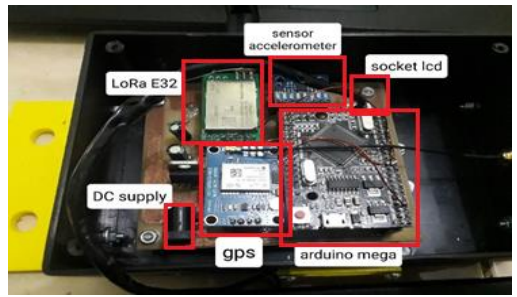

Gbr. 7 Node Device

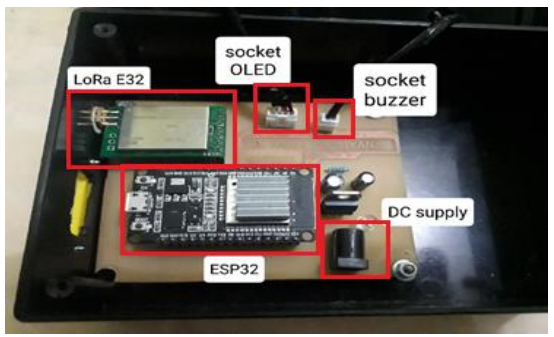

Gbr. 8 Gateway

\section{B. Pengujian Unit}

1) Pengujian GPS Receiver

Pengujian GPS receiver dilakukan dengan membandingkan koordinat unit dengan Google maps dengan titik yang dinamis atau berpindah pindah, hasil pengujian pembacaan GPS receiver ublox m8 seperti pada Tbl. 3 .

Tbl. 3 Hasil Pengujian GPS Ublox M8

\begin{tabular}{ccccccc}
\hline \multirow{2}{*}{ Pengujian ke- } & \multicolumn{2}{c}{ Pembacaan Sensor } & \multicolumn{2}{c}{ Pembacaan Google maps } & \multicolumn{2}{c}{ Error Pembacaan } \\
\cline { 2 - 7 } & Latitude & Longitude & Latitude & Longitude & Latitude & Longitude \\
\hline 1 & $-7,343199$ & 108,223654 & $-7,343095$ & 108,223678 & $0,01040000 \%$ & $0,00002218 \%$ \\
\hline 2 & $-7,342752$ & 108,223683 & $-7,342851$ & 108,223716 & $0,00990000 \%$ & $0,00003049 \%$ \\
\hline 3 & $-7,342752$ & 108,223683 & $-7,342839$ & 108,223724 & $0,00870000 \%$ & $0,00003788 \%$ \\
\hline 4 & $-7,342665$ & 108,223441 & $-7,342856$ & 108,223518 & $0,01910000 \%$ & $0,00007115 \%$ \\
\hline 5 & $-7,342789$ & 108,223403 & $-7,342872$ & 108,223472 & $0,00830000 \%$ & $0,00006376 \%$ \\
\hline 6 & $-7,342862$ & 108,223354 & $-7,342874$ & 108,223434 & $0,00120000 \%$ & $0,00007392 \%$ \\
\hline 7 & $-7,342861$ & 108,223389 & $-7,342878$ & 108,223434 & $0,00170000 \%$ & $0,00004158 \%$ \\
\hline 8 & $-7,339884$ & 108,226784 & $-7,339924$ & 108,226791 & $0,00400000 \%$ & $0,00000647 \%$ \\
\hline 9 & $-7,339884$ & 108,226784 & $-7,339918$ & 108,226783 & $0,00340000 \%$ & $0,00000092 \%$ \\
\hline 10 & $-7,339988$ & 108,226914 & $-7,339983$ & 108,226898 & $0,00050000 \%$ & $0,00001478 \%$ \\
\hline \multicolumn{7}{c}{ rata-rata } \\
\hline
\end{tabular}

Dari hasil pengujian GPS Receiver pada Tbl. 3 dengan pengujian sebanyak 10 kali pengambilan koordinat posisi dan dibandingkan dengan pembacaan koordinat posisi aplikasi google maps, maka jika dirata-ratakan untuk error pembacaan latitude yaitu sebesar $0,00672 \%$ dan longitude sebesar $0,00003871 \%$.
2) Pengujian Sensor Accelerometer

Pengujian dilakukan dengan membandingkan sudut pembacaan sensor accelerometer dengan pengukuran busur derajat. Hasil pengujian Accelerometer Gy-521 pada Tbl.4. 
Tbl. 4 Hasil Pengujian Accelerometer Gy-521

\begin{tabular}{ccccccc}
\hline Pengujian Ke- & \multicolumn{3}{c}{ Pembacaan Sensor di sudut- } & \multicolumn{3}{c}{ Error Pembacaan } \\
\cline { 2 - 6 } & $15^{\circ}$ & $30^{\circ}$ & $45^{\circ}$ & $15^{\circ}$ & $30^{\circ}$ & $45^{\circ}$ \\
\hline $\mathbf{1}$ & $12^{\circ}$ & $26^{\circ}$ & $43^{\circ}$ & $20,00 \%$ & $13,33 \%$ & $4,44 \%$ \\
\hline $\mathbf{2}$ & $11^{\circ}$ & $27^{\circ}$ & $42^{\circ}$ & $26,67 \%$ & $10,00 \%$ & $6,67 \%$ \\
\hline $\mathbf{4}$ & $11^{\circ}$ & $27^{\circ}$ & $44^{\circ}$ & $26,67 \%$ & $10,00 \%$ & $2,22 \%$ \\
\hline $\mathbf{5}$ & $11^{\circ}$ & $27^{\circ}$ & $42^{\circ}$ & $26,67 \%$ & $10,00 \%$ & $6,67 \%$ \\
\hline $\mathbf{6}$ & $12^{\circ}$ & $26^{\circ}$ & $44^{\circ}$ & $20,00 \%$ & $13,33 \%$ & $2,22 \%$ \\
\hline $\mathbf{7}$ & $11^{\circ}$ & $27^{\circ}$ & $44^{\circ}$ & $26,67 \%$ & $10,00 \%$ & $2,22 \%$ \\
\hline $\mathbf{8}$ & $13^{\circ}$ & $27^{\circ}$ & $42^{\circ}$ & $13,33 \%$ & $10,00 \%$ & $6,67 \%$ \\
\hline $\mathbf{9}$ & $11^{\circ}$ & $27^{\circ}$ & $42^{\circ}$ & $26,67 \%$ & $10,00 \%$ & $6,67 \%$ \\
\hline $\mathbf{1 0}$ & $11^{\circ}$ & $26^{\circ}$ & $42^{\circ}$ & $26,67 \%$ & $13,33 \%$ & $6,67 \%$ \\
\hline & $11^{\circ}$ & $27^{\circ}$ & $43^{\circ}$ & $26,67 \%$ & $10,00 \%$ & $4,44 \%$ \\
\hline
\end{tabular}

Dari hasil pengujian sensor accelerometer Gy-521 MPU6050 diperoleh hasil rata rata Error pembacaan yang berbeda-beda, yaitu kesalahan pembacaan cenderung menurun seiring semakin besarnya derajat pembacaan, diperoleh Besar error rata-rata pada sudut $15^{\circ}$ yaitu sebesar $24 \%$, pada sudut $30^{\circ}$ sebesar $11 \%$, dan pada sudut $45^{\circ}$ yaitu sebesar $4,89 \%$.

\section{Pengujian Sistem}

\section{1) Pengujian Keandalan Komunikasi LoRa}

Pengujian dilakukan dengan mengirimkan data string dengan panjang yang berbeda-beda $(10,25,55)$, pada jarak (500, 1000, 1500, 2400, 2500 meter) dan tinggi (1 dan 12 meter diatas permukaan tanah), dengan pengaturan data rate 300, 2400, 19200 bps pada keadaan LOS (Line Of Sight). Pengaturan data rate LoRa menggunakan program pada Pengujian dilakukan di pantai Pangandaran dengan menerapkan node device pada perahu (Gbr. 9) dan gateway di bibir pantai (Gbr. 10).

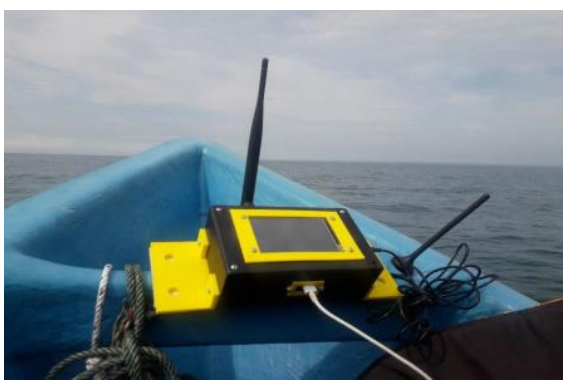

Gbr. 9 Penerapan Node device

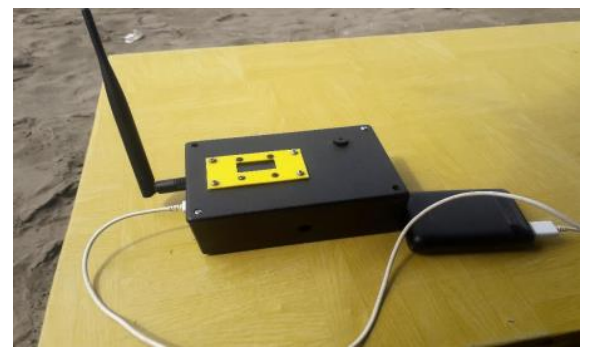

Gbr. 10 Penempatan gateway

Time on air dihitung dengan memanfaatkan waktu millis pada mikrokontroler, dengan menyimpan waktu kirim (Gbr. 11) dan waktu terima feedback (Gbr. 12) pada sebuah variabel.

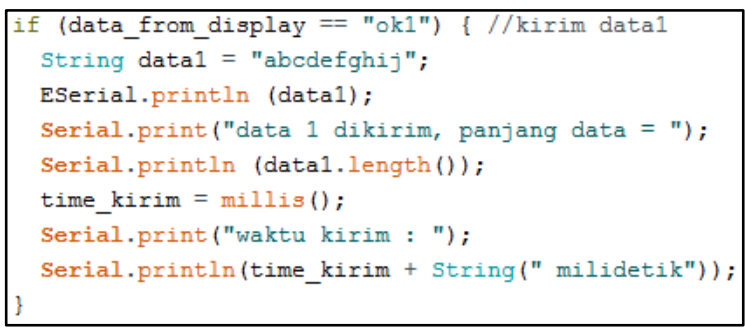

Gbr. 11 Sketch waktu kirim

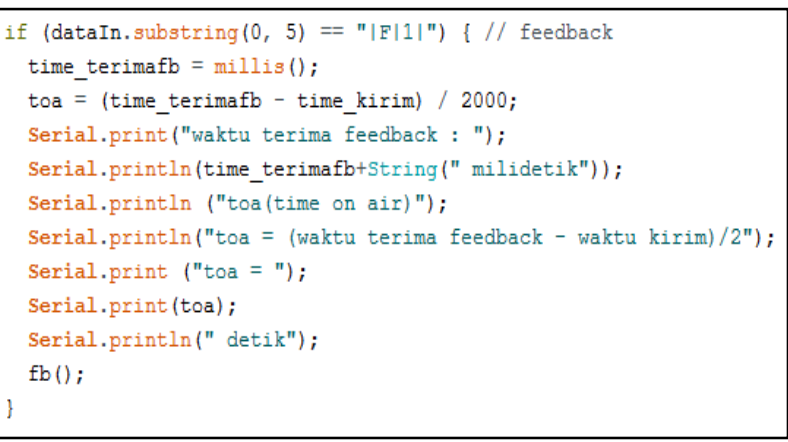

Gbr. 12 Sketch waktu terima feedback

Sehingga Time on air dapat dicari seperti pada (2).

$$
\text { ToA }(\text { detik })=\frac{(\text { Tterimafb }- \text { Tkirim })}{2}
$$

Hasil Pengujian data rate 300 bps pada ketinggian 1 meter seperti pada Gbr. 13. Time on air pada data rate 300 bps dan tinggi gateway \pm 1 meter, bertambah lama seiring dengan bertambah panjangnya data yang dikirim, dan mencapai jarak 2,4 km.

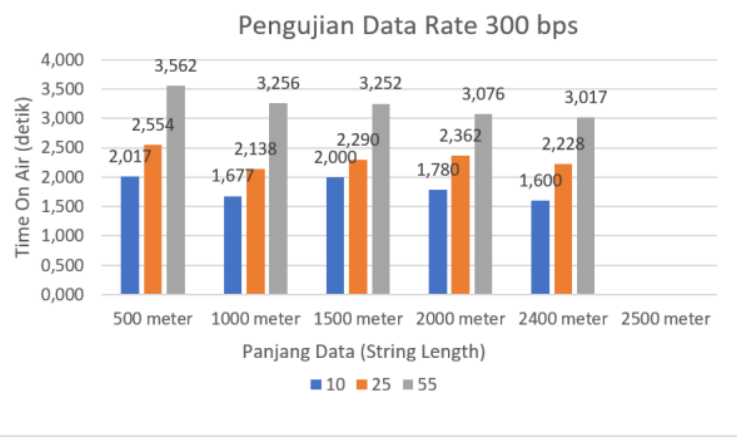

Gbr. 13 Pengujian data rate 300 bps 
Hasil Pengujian data rate 2400 bps pada ketinggian 1 meter terlihat pada Gbr. 14. Time on air pada data rate 2400 bps dan tinggi gateway \pm 1 meter, fluktuatif seiring bertambah panjangnya data, dan mencapai jarak $1 \mathrm{~km}$.

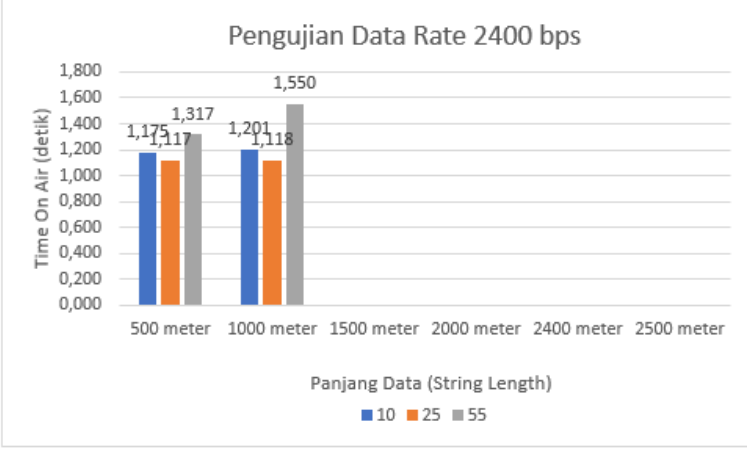

Gbr. 14 Pengujian data rate 2400 bps

Hasil Pengujian data rate 19200 bps pada ketinggian 1 meter terlihat pada Gbr. 15. Time on air pada data rate 19200 bps dan tinggi gateway \pm 1 meter bertambah lama seiring bertambah panjangnya data.

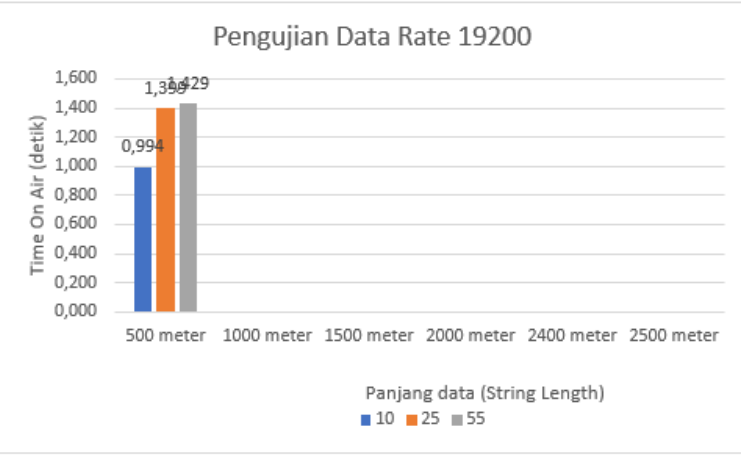

Gbr. 15 Pengujian data rate 19200 bps

Pada pengujian pengaruh ketinggian, gateway diletakkan di menara pengawas pantai yang memiliki ketinggian 12 meter (Gbr . 16). Dengan jarak 500 meter dengan data rate yang berbeda beda (300, 2400, 19200 bps).

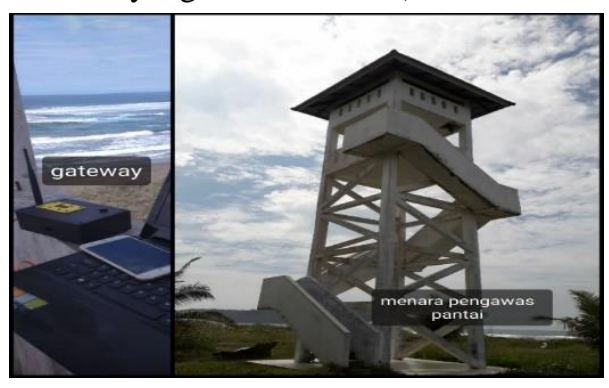

Gbr. 16 Penempatan Gateway pada menara pengawas pantai

Hasil Pengujian pada jarak 500 meter pada ketinggian 12 meter terlihat pada Gbr. 17. Hasil pengujian menunjukkan time on air pada data rate 300 bps meningkat seiring bertambah panjangnya data, pada data rate 2400 bps fluktuatif seiring bertambahnya data, dan pada data rate 19200 bps menurun seiring bertambah panjangnya data.

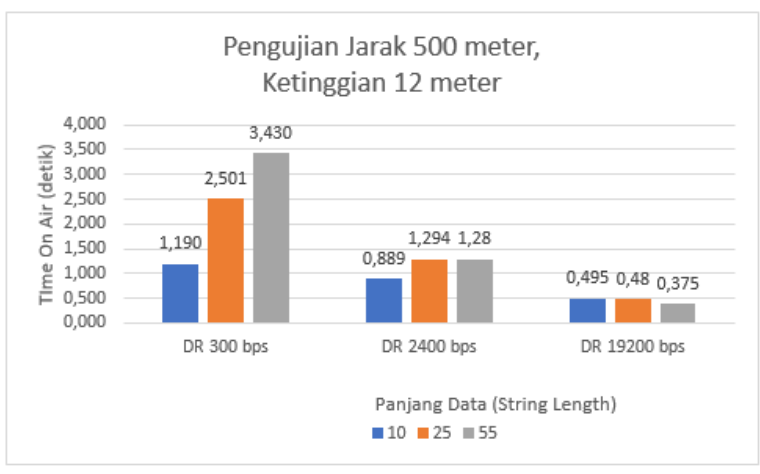

Gbr. 17 Pengujian ketinggian 12 meter

2) Pengujian MQTT Broker dan Thingsboard

Pengujian dilakukan dengan mengirimkan data telemetry dari gateway ke thingsboard dengan melalui server iotee.unsil.ac.id. Hasil pengujian dapat dilihat pada Tbl. 5.

Tbl. 5 Hasil pengujian pengiriman data ke MQTT Broker

\begin{tabular}{|c|c|c|c|c|c|}
\hline \multirow{2}{*}{$\begin{array}{l}\text { Pengujian } \\
\text { ke- }\end{array}$} & \multicolumn{5}{|c|}{ Data Diterima } \\
\hline & Latitude & Longitude & Roll & Pitch & status \\
\hline 1 & 7,340271 & 108,22615 & 13 & 9 & AMAN \\
\hline 2 & 7,340271 & 108,22615 & 3 & 4 & AMAN \\
\hline 3 & 7,340271 & 108,22615 & 8 & 11 & AMAN \\
\hline 4 & 7,340271 & 108,22615 & 11 & 9 & AMAN \\
\hline 5 & 7,340271 & 108,22615 & 8 & 5 & AMAN \\
\hline 6 & 7,340271 & 108,22615 & 13 & 11 & AMAN \\
\hline 7 & 7,340271 & 108,22615 & 9 & 3 & AMAN \\
\hline 8 & 7,340271 & 108,22615 & 14 & 10 & AMAN \\
\hline 9 & 7,340271 & 108,22615 & 5 & 2 & AMAN \\
\hline 10 & 7,340271 & 108,22615 & 6 & 11 & AMAN \\
\hline
\end{tabular}

Data yang masuk ke thingsboard akan langsung terlihat pada latest data telemetry pada device detail, seperti pada Gbr. 18.

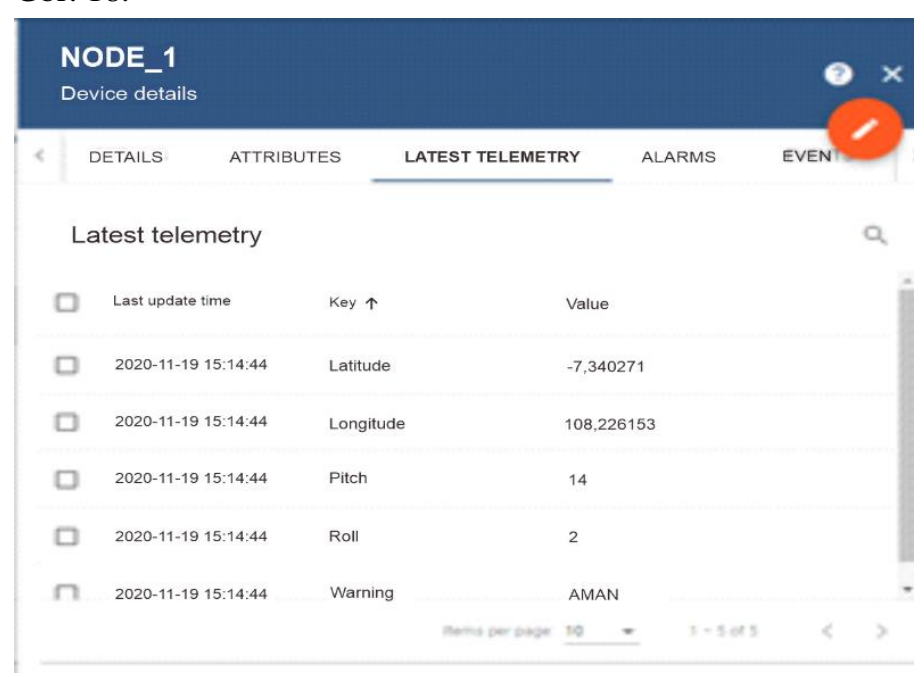

Gbr. 18 Latest data telemetry thingsboard

Data akan tampil pada dasbor thingsboard seperti pada Gbr. 19. 


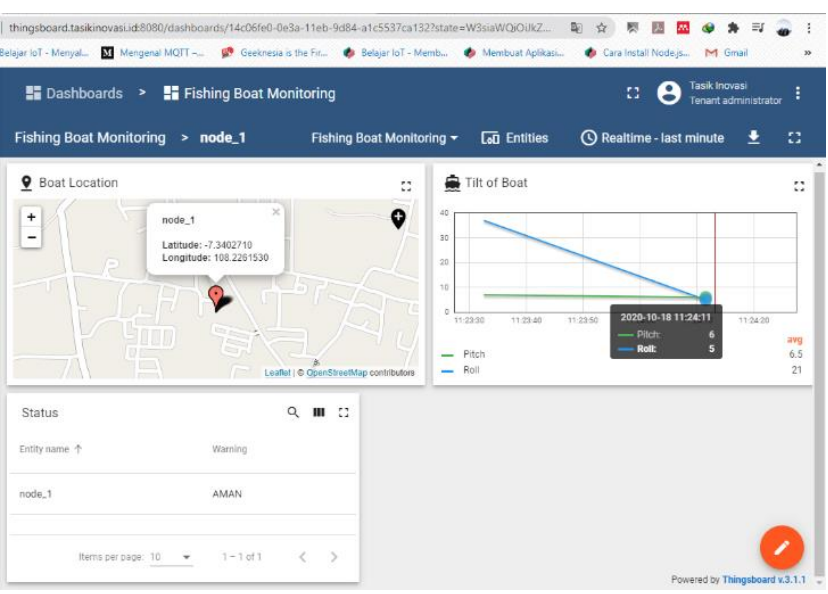

Gbr. 19 Dasbor thingsboard

\section{KESIMPULAN}

1) Dari Hasil Pengujian maka sistem mampu mendeteksi lokasi, kemiringan perahu dengan menggunakan GPS receiver Ublox M8 dan Sensor accelerometer Gy-521 dengan persen error pembacaan GPS kurang dari $0,01 \%$ dan persen error pembacaan sensor accelerometer Gy-521 paling tinggi mencapai $27 \%$.

2) Modul Komunikasi yang digunakan yaitu LoRa E32 915T20D yang memiliki transmit power 20dbm mampu menjangkau jarak terjauh hingga $2,4 \mathrm{~km}$ dengan konfigurasi kecepatan kirim/ data rate pada 300 bps, dengan time on air cenderung meningkat seiring bertambah panjangnya data. Data yang dikirimkan berupa data string dengan variasi panjang data dalam pengujian yaitu 10, 25 dan 55. Dan akan lebih meningkatkan kualitas pengiriman data apabila gateway diletakkan di atas ketinggian tertentu sehingga tidak terdifraksi oleh media hambatan apapun (seperti tanah, air dan media lainnya).

3) Data perahu berhasil dikirimkan oleh gateway menuju MQTT broker sehingga perahu dapat termonitoring secara online melalui dasbor thingsboard.

\section{REFERENSI}

[1] Komite Nasional Keselamatan Transportasi, 'STATUS LAPORAN Kecelakaan Lalu Lintas dan Angkutan Jalan ( LLAJ )', no. November, 2018.

[2] O. Yaakob, F. E. Hashim, M. R. Jalal, and M. A. Mustapa, 'Stability, seakeeping and safety assessment of small fishing boats operating in southern coast of Peninsular Malaysia', J. Sustain. Sci. Manag., vol. 10, no. 1, pp. 50-65, 2015.

[3] N. Hiron and A. Andang, 'Wireless communication with batching method based on Xbee-PRO S2B module for sensing of wind speed', Proceeding - 2016 2nd Int. Conf. Sci. Inf. Technol. ICSITech 2016 Inf. Sci. Green Soc. Environ., pp. 250-253, 2017.

[4] R. Sanchez-Iborra and M. D. Cano, 'State of the art in LP-WAN solutions for industrial IoT services', Sensors (Switzerland), vol. 16, no. 5, 2016.

[5] Semtech Corporation, 'SX1272/3/6/7/8 LoRa Modem Design Guide, AN1200.13', no. July, p. 9, 2013.

[6] J. Matondang, 'Prinsip Spread Spectrum dan Contoh Aplikasinya: LoRa', 2018. [Online]. Available: https://josefmtd.com/2019/05/16/prinsip-spreadspectrum-dan-contoh-aplikasinya-lora/. [Accessed: 24Apr-2020].

\section{BIOGRAFI PENULIS}

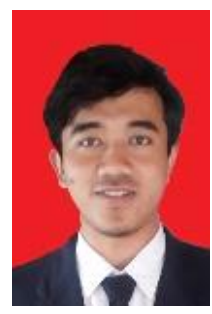

Fadli Padriyana, Lahir pada tanggal 2 Februari 1999 di Kabupaten Kuningan, Jawa Barat. Sedang menempuh studi S1 sejak tahun 2016 di Universitas Siliwangi, Fakultas Teknik, Prodi Teknik Elektro, Mengambil konsentrasi Sistem Kendali di Prodi Teknik Elektro.

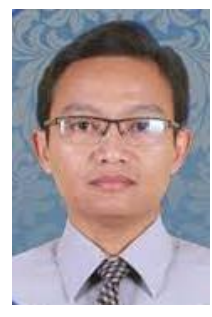

Firmansyah M.S.N., Lahir di xxxx. Bekerja sebagai tenaga pengajar di Program Studi Informatika Universitas Siliwangi dengan bidang konsentrasi xxxx.

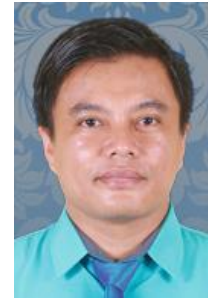

Nurul Hiron, Lahir di Balikpapan, 19 Agustus 1975. Bekerja sebagai tenaga pengajar di Program Studi Teknik Elektro Universitas Siliwangi dengan bidang konsentrasi ilmu manajemen energi. 